\title{
English Songs as Means of Aiding Students' Proficiency Development
}

\author{
Roszainora Setia ${ }^{1}$, Rozlan Abdul Rahim ${ }^{1}$, Gopala Krishnan Sekharan Nair ${ }^{1}$, Aileen Farida binti Mohd Adam ${ }^{1}$, \\ Norhayati Husin ${ }^{1}$, Elangkeeran Sabapathy ${ }^{1}$, Razita Mohamad ${ }^{1}$, Shahidatul Maslina Mat So'od ${ }^{1}$, Nurul Izatee Md \\ Yusoff $^{1}$, Razifa Mohd Razlan ${ }^{1}$, Nur Amalia Abd Jalil ${ }^{1}$, Rozita Mohamed Kassim² \& Norhafiza Abu Seman ${ }^{3}$ \\ ${ }^{1}$ Academy of Language Studies, Universiti Teknologi MARA (UiTM), Dungun, Malaysia \\ ${ }^{2}$ Sultan Omar Secondary School, Dungun, Malaysia \\ ${ }^{3}$ Faculty of Administrative Science and Policy Studies, Universiti Teknologi MARA (UiTM), Dungun, Malaysia \\ Correspondence: Roszainora Setia, Academy of Language Studies, Universiti Teknologi MARA (UiTM), \\ Dungun Campus, 23000 Dungun, Malaysia. E-mail: gopal792@tganu.uitm.edu.my
}

Received: December 30, $2011 \quad$ Accepted: January 30, $2012 \quad$ Published: June 1, 2012

doi:10.5539/ass.v8n7p270 URL: http://dx.doi.org/10.5539/ass.v8n7p270

\begin{abstract}
The major aim of this research is to determine the effectiveness of using songs in teaching English language to primary school students. This research will specifically investigate to what extent songs can contribute to the development of students' language proficiency. The research is designed to find out whether using songs can be an effective way in creating positive attitude and motivation in language learners. The research will be carried out through the use of questionnaire. The data will be analyzed using the SPSS software to determine the best statistical technique to be used to test the hypotheses and to interpret the result. This is a preliminary survey research and it is hoped that this research will give an opportunity to teachers to realize songs help improve students' language proficiency. From the survey, it has been discovered that the use of song not only helps the understanding, it also stimulates and increases the students' interest to learn, enjoy and engage in the learning process. Furthermore, it accelerates students' confidence, learning ability and skill when activities are highly motivated and memorable. Future researchers should extend this research to other samples in other localities and cultures.
\end{abstract}

Keywords: teaching effectiveness, songs, primary school, motivation

\section{Introduction}

The use of conventional method in teaching English language such as explaining and drilling are unattractive and can be very dull to the students. Hence, this will inevitably affect and obstruct their spirit to learn the language. To meet the demands of the challenging world in the era of globalization, the Curriculum Development Centre (CDC) of Malaysia has revised the English language syllabus for primary and secondary schools in 2002. The rationale is to help the students of different ability by allowing for mastery of structures and vocabulary. The new syllabus is developed to depict the natural use of language in the real world so that students can use the language and perform satisfactorily in both the professional and social aspect of their life.

One of the ways to achieve the mastery of English is by using songs. Song is a form of language that uses tones and rhythm as it is also the media of universal language. Language and music are known to have similar communicative modes; aurally and orally transmitted, containing phonetic, syntactic and semantic components; develop early in life as social interactive media.

According to Peacock (1997), many writers share the same opinion that learners are more motivated and stimulated in the foreign language classroom when authentic materials are used than the artificial non-authentic materials. He further concludes that the authentic materials such as American pop song increased students' level of non-task behaviour. They display a high level of involvement and concentration in authentic materials more than the artificial materials. Orlava (2003), state that there is a great connection between students' motivation and authentic materials. It is a very good way to expose the targeted language to the learners as well as facilitating their learning. 
Therefore, this research is an attempt to investigate the effectiveness of using songs to enhance students' motivation in learning English in primary school students. In addition, it is also to examine whether songs can create positive attitudes among students during a language lesson.

\section{Literature Review}

The concept of songs has been found to have positive effects on the classroom climate. The most successful lessons are the ones which give us the feeling of enjoyment and good time. Enjoyable learning has to be more effective than teacher-centered procedures. Music is a proven teaching tool which fosters language retention and production in young learners Medina (1993). Using music in the classroom will help your students succeed as EFL students Jalongo and Bromley (1984).

Singing songs not only help many students remember important information but it also make the classroom learning more lively, as stated by Campbell, Campbell \& Dickinson (1996). Most of the past researchers revealed that using songs give a great influence in educational settings.

Aksnes (1996), find out that the use of different stimuli to improve language acquisition is a paramount strategy. Teaching language through music enhances not only linguistic competence and performance, but also perception skills.

In short, Coromina (2010), defends that a good song can prompt interesting discussion in class. When students enjoy learning English through songs, they will indirectly make the effort to learn the lyrics of the songs they are listening to.

Neurologists have also found that musical and language processing occur in the same area of the brain, and there appear to be parallels in how musical and linguistic syntax are processed Maess et. al. (2001). In one study, college students demonstrated improved short-term spatial reasoning ability after listening to Mozart. This was dubbed the "Mozart effect" in the popular press Rauscher et. al. (1993).

Adult learners in South Africa exposed to instrumental music during an intensive English course, showed benefits in language learning Puhl (1989). Many educators report success using instrumental music as a warm up and relaxation tool, as a background for other activities, and as the inspiration for writing activities Eken (1996).

Griffee (1990), recommended using short, slow songs for beginning-level students and discusses activities such as creating song word puzzle, drawing a song, or showing related pictures. Murphey (1992), found that the majority of English language teachers all over the world use or have used songs for teaching purposes. According to him, it seems that songs lodge in both our short and long memory so they are a relatively easy way to remember quite long chunk of language. In his study, He also found out that songs may be exploited as effectively as any other text. They can be a source of language for presenting and practicing grammar and syntax, vocabulary, pronunciation, and the skills of listening, reading, speaking, writing and translation.

The use of songs as material is believed to help introducing the individuals with sounds, stress and rhythmic patterns, vocabulary, intonation, grammatical and conversational exchanges Davanellos and Akis (1999). Music positively affects language accent, memory, and grammar as well as mood, enjoyment, and motivation. Therefore, teachers and educators should feel confident using music to facilitate the language acquisition process. Clearly, there are numerous benefits associated with it.

Furthermore, using songs in the second language classroom is supported by the work of another theorist, Gardner, (1998). According to this psychologist, there are eight distinct intelligence exist in humans; musical, spatial, logical-mathematical, linguistic, bodily kinesthetic (movement), interpersonal (understanding other) and intrapersonal (understanding self) and naturalist (observing and understanding natural and human made patterns and systems). Using songs and music as a vehicles for second language learning is inconsistent with Gardner's theory of multiple intelligences.

\section{Methodology}

\subsection{Sampling}

In conducting this research, the method used is survey questionnaire. The questionnaire was self-developed and pilot tested prior to its use. The purpose is to gather information and to seek out details on the students' background and how they have learned and been exposed to English language. It is also to determine students' interest and their reaction toward the approach used. Lastly, it is aimed to observe the students' attitude and behavior towards the approach used. 
These questionnaires were given to sixty (61) students from a private primary Islamic school in Dungun. These students are those from upper level namely, year 4, year 5 and year 6 who have been exposed to a certain level in learning English through songs.

The questionnaire consists of six sections. Section A focuses on the demographic data. Section B of the questionnaire focuses on whether students enjoy learning English more through songs.

Section $\mathrm{C}$ needs the students to state their opinion of whether learning English through songs increase their range of vocabulary or vice versa. Section D ventures into students' preference and types of song that they would choose to hear when learning English. Meanwhile, section E attempts to ask students regarding their improvement in pronunciation when they learn English through songs. The last section $\mathrm{F}$ is regarding their confidence level when songs are used in the English lesson.

For Section B to F, the 5-point Likert Scale is used to measure the level of agreement or disagreement of the statement in the questionnaire.

\subsection{Data Analysis}

After collecting the data from the questionnaires, the researcher analyzed the data for the purpose of answering the research questions. The questionnaires were analyzed using Statistical Program for Social Sciences (SPSS).

\section{Results and Discussion}

4.1 The Use of Songs in Making English Learning Enjoyable

Table 1. Learning English is more enjoyable when songs are used

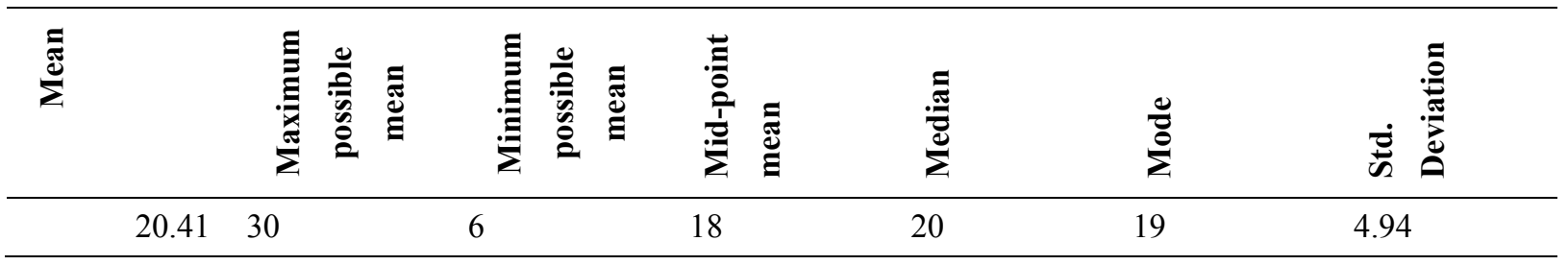

Table 1 shows the mean score is 20.41 and it is higher than the mid point value of 18 . Therefore, it shows that students do enjoy learning English more if songs are used to teach English. In terms of students' perception, they look forward to such an approach. When songs are used, students would be interested to know the authentic meaning of the songs. Therefore, based on the analysis above, it can be concluded that using songs to teach English make students enjoy learning English compared to traditional text book methods.

4.2 The Use of Songs in Improving Students' Range of Vocabulary

Table 2. Songs help to increase students' range of vocabulary

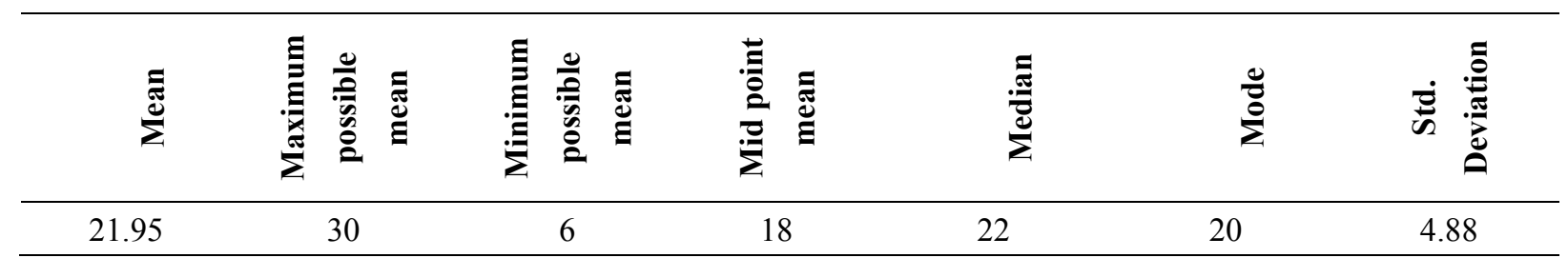

Table 2 above shows the mean score is 21.95 and it is higher than the mid point value of 18 . It proves a strong and significant correlation between the teaching approach and the performance of the students. According to the students, songs help them remember new words better and it lasts longer in their memory box. Then, a conclusion can be made that the students' vocabulary expands when they learn new words via songs.

4.3 The Relationship of Types of Songs and Students' Excitement in Learning English

Table 3. Types of songs influence students' excitement

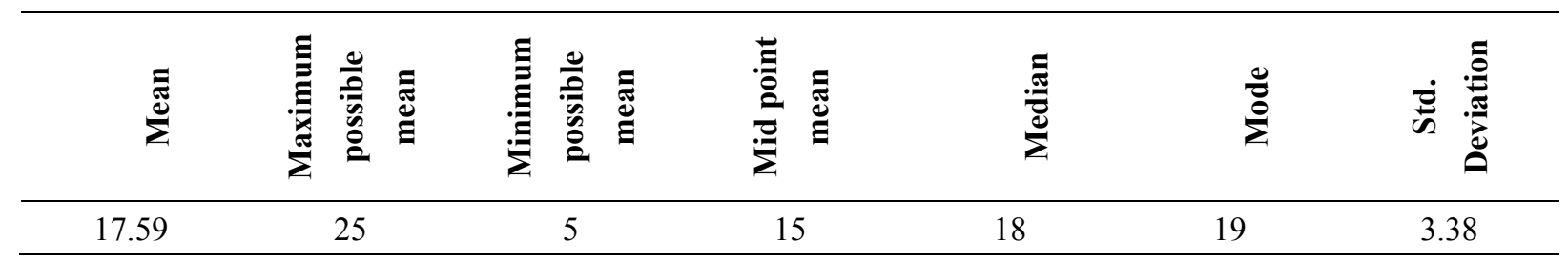

Table 3 shows that the mean value 17.59 is higher than the mid point value of 15 . Students love to listen to songs 
which have simple lyrics and simple language. Therefore, it is not surprising to discover that the type of songs chosen has some effect on the students' excitement in learning English.

\subsection{The Use of Songs in Improving Students' Pronunciation}

Table 4. Songs help to improve students' pronunciation

\begin{tabular}{|c|c|c|c|c|c|c|c|}
\hline 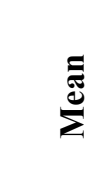 & 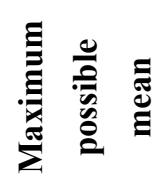 & 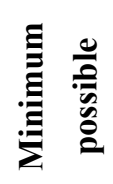 & $\stackrel{\Xi}{\Xi}$ & 芯 & & 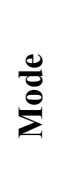 & D \\
\hline 19.92 & 25 & 5 & & 15 & 20 & 25 & 3.58 \\
\hline
\end{tabular}

Table 4 shows that the mean value obtained by the 61 respondents on whether their pronunciation improves when songs are used to teach English is 19.92. This is far higher than the mid point value of 15. The students enjoy pronouncing the words in songs and consequently, their pronunciation improves. In addition to the above result, they are more confident to pronounce the words loudly in class

\subsection{The Usage of Songs in Boosting Students' Confidence}

Table 5. Songs make students more confident

\begin{tabular}{|c|c|c|c|c|c|c|c|}
\hline 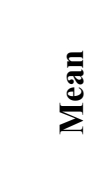 & 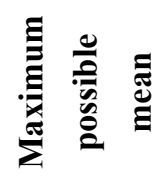 & $\stackrel{\Xi}{\stackrel{E}{E}}$ & 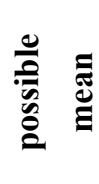 & 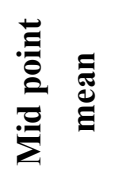 & 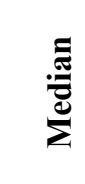 & $\frac{\mathscr{e}}{\tilde{E}}$ & 这 \\
\hline 30.39 & 40 & & 8 & 24 & 30 & 30 & 5.88 \\
\hline
\end{tabular}

Table 5 shows that the mean is far higher than the mid-point value. The mean value of 30.39 compared to mid point value of 24 is self explanatory. Students feel that their confidence level can be increased when songs are used to teach English. As a conclusion, learning English through songs increases the students' learning ability.

Table 6. Summary of the scores

\begin{tabular}{|c|c|c|c|c|c|c|c|c|c|}
\hline 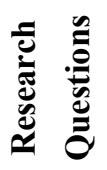 & 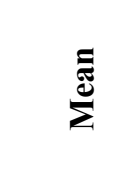 & 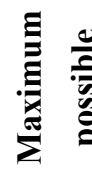 & $\stackrel{\Xi}{\Xi}$ & 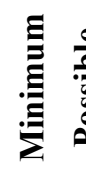 & 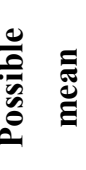 & 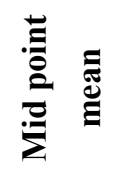 & & $\frac{8}{\stackrel{0}{0}}$ & 密 \\
\hline 1 & 20.41 & 30 & & & 6 & 18 & 20 & 19 & 4.94 \\
\hline 2 & 21.95 & 30 & & & 6 & 18 & 22 & 20 & 4.88 \\
\hline 3 & 17.59 & 25 & & & 5 & 15 & 18 & 19 & 3.38 \\
\hline 4 & 19.9 & 25 & & & 5 & 15 & 20 & 25 & 3.58 \\
\hline 5 & 30.39 & 40 & & & 8 & 24 & 30 & 30 & 5.88 \\
\hline
\end{tabular}

The summary in the table 6 above indicates that all 61 respondents have positive perception when songs are used in their English lessons. The table is used to show the scores obtained from the study where all the means exceed the mid-point values. This shows that, according to students' perception, songs could be an authentic and effective mechanism in learning English.

\section{Conclusion}

Based on the above study and findings, it can be concluded that the majority of the subjects agreed that using songs to learn English is an effective tool in acquiring vocabulary and improving pronunciation. Songs should be implemented in the teaching and learning of English language as it can make remarkable changes in the language 
learning field. The enthusiasm generated by songs will ensure that students remember not only the meaning but are also able to pronounce and spell the words and phrases correctly.

The exposure to authentic English is an important factor in promoting language learning. It relates directly to both the affective filter and automaticity. If students are exposed to songs which they enjoy, more meaningful learning is likely to occur since they may also find and listen to the music outside of the classroom. The repetitive style of songs then helps to promote automatization of colloquial language. It is an urgent need to promote these essential practices in order to get more excellent users of language. It is important to take into consideration the educational factors in this study when designing the type of lesson that will motivate the students to acquire vocabulary.

The results from the survey show that students are interested and motivated to improve their English proficiency level when songs are introduced in this initial study. Songs will create a more relaxed and conducive learning environment to the students and as a result the students are more excited to learn English using songs.

Thus, the use of songs serves the purpose of teaching language effectively and efficiently. Songs should be carefully selected to suit the students' abilities and the lyrics should be clear and the vocabulary in the songs should be appropriate to the students' proficiency levels.

\section{References}

Aksnes, H. (1996). Research on memory related to language, Daros, M., Gurney, D. (Eds). Retrieved October 13, 2008, from http://www.pegasus.cc.ucf.edu/gurney/LangConn.html

Campbell, L, Campbell, B., \& Dickinson, D. (1996). Teaching \& Learning through Multiple Intelligenge. Massachusetts: Allyn \& Bacon.

Coromina, S. (n.d). An Approach to the Teaching Songs in the Classroom. Kennedy.Byu.edu. Retrieved 3 October, 2010, from http://kennedy.byu.edu/partners

Davanellos, Akis. (1999). Songs: English Teaching Professional. Issue Thirteen October.

Eken, D. K. (1996). Ideas for using songs in the English language classroom. English Teaching Forum, 34(1), 46-47.

Gardner, H. (1998). Reflections on multiple intelligences: Myths and messages. In A. Woolfolk (Ed.), Readings in educational psychology. Boston: Allyn \& Bacon.

Griffee, D. T. (1990). Hey baby! Teaching short and slow songs in the ESL classroom. TESL Reporter, 23(4), 3-8.

Jalongo, M., \& Bromley, K. (1984). Developing linguistic competence through song. Reading Teacher, 37(9), 840-845.

Maess B, Koelsch S, Gunter TC., \& Friederici AD. (2001). Musical syntax is processed in Broca's area: An MEG study. Nature Neurosci, 4, 540-545.

Medina, S. (1993). The effect of music on second language vocabulary acquisition. FEES News (National Network for Early Language Learning), 6(3), 1-8.

Murphey, T. (1992). The discourse of pop songs. TESOL Quarterly, 26(4), 770-774. http://dx.doi.org/10.2307/3586887

Orlava, N. F. (2003, March). Helping Prospective EFL Teachers Learn How to Use Songs in Teaching Conversation Class. The Internet TESL Journal, IX(3). Retrieved 24 September, 2010, from http://iteslj.org/

Peacock, M. (1997). The Effects of Authentics Materials on EFL Learners. ELT Journal, 51(2). London: Oxford University Press.

Puhl, C. A. (1989). Up from under: English training on the mines. (Report on 1988 research project conducted at Gold Field Training Services). Stellenbosch, South Africa: University of Stellenbosch. (ED No. 335864). Retrieved from http://search.sweetim.com/search.asp?ln=en\&src=1001\&q=puhl+1989

Rauscher, F. H., Shaw, G., \& Ky, K. (1993). Mozart and spatial reasoning. Nature, (365), 611. http://dx.doi.org/10.1038/365611a0 